UDC: 330.341

\author{
A. Rusnak, \\ Doctor of Economic Sciences, Professor, Professor of the Department of Economics, \\ Kherson Branch of the Admiral Makarov National University of Shipbuilding, Kherson, Ukraine \\ ORCID ID: 0000-0002-3198-2866 \\ D. Lomonosov, \\ PbD in Economics, Associate Professor, Associate Professor of the Department of Economics, \\ Kherson Branch of the Admiral Makarov National University of Shipbuilding, Kherson, Ukraine \\ ORCID ID: 000-0003-4394-1807
}

DOI: $10.32702 / 2306-6814.2021 .11 .11$

\title{
METHODOLOGY FOR DETERMINING THE EFFECTIVENESS OF INNOVATION ACTIVITIES IN AN INDUSTRIAL ENTERPRISE
}

\author{
А. В. Руснак, \\ А. е. н., професор, професор кафедри економіки, Херсонська філія \\ Національного університету кораблебудування імені адмірала Макарова, м. Херсон, Україна \\ А. А. Аомоносов, \\ к. е. н., доцент, доцент кафедри економіки, Херсонська філія \\ Національного університету кораблебудування імені адмірала Макарова, м. Херсон, Україна
}

\section{МЕТОАИКА ВИЗНАЧЕННЯ ЕФЕКТИВНОСТІ ІННОВАЦІЙНОЇ АІЯ АЬНОСТІ НА ПРОМИСАОВОМУ ПІАПРИЕМСТВІ}

The article substantiates the expediency of using methods of portfolio planning of innovation activities, as well as conducting a comparative assessment of the effectiveness of innovative projects considered in the formation of the innovation portfolio of the enterprise. It is determined that the system of innovation activity indicators should include not only financial indicators (ROI, share of profit from implementing innovations, etc.), but also qualitative indicators (share of ideas implemented in the company; average time elapsed from submission of a new innovative proposal to the decision to launch or abandon an innovative project, etc.). The dynamics of changes in qualitative indicators will help identify problems in the innovation management system in time and take measures before a crisis occurs. We propose the use of a balanced scorecard to assess the innovation activities of an enterprise, which includes indicators that characterize the enterprise strategy from four different and yet interrelated perspectives: finance perspective; training and personnel development; internal business processes; and customer perspective. Based on individually developed performance indicators and subsequent comparison of planned and actual data, senior managers receive information that allows them to assess the effectiveness of the implementation of strategies in four main areas. The balanced scorecard for innovation activity is a kind of monitoring tool and an effective tool for both current and long-term management of an enterprise's strategy. We have generalized and improved the methodology for assessing the economic efficiency of the organization of innovation activity in an industrial enterprise using a generalizing indicator of the efficiency of the enterprise as a whole. The proposed system of indicators of innovative activity will help the enterprise to analyse its ability to innovative work, quality of realization of this work, and will allow assessing the innovative activity of the enterprise, competitiveness of products and firm as a whole, etc.

Метою статті є розробка методики визначення ефективності інноваційної діяльності промислового підприємства як збалансованої системи показників. У статті обгрунтовано доцільність 
використання методів портфельного планування інноваційної діяльності, а також проведення порівняльної оцінки ефективності інноваційних проектів, що розглядаються під час формування інноваційного портфеля підприємства. Визначено, що система показників інноваційної діяльності повинна включати не тільки фінансові (ROI, частка прибутку від реалізації нововведень), але і якісні показники (частка реалізованих у компанії ідей, середній час, що минув з моменту подачі нової інноваційної пропозиції до рішення про запуск або відмову від реалізації інноваційного проекту). Динаміка змін якісних показників допоможе вчасно виявити проблеми в системі управління інноваціями та вжити заходів до настання кризи. Нами запропонованодля оцінки інноваційної діяльності підприємства використовувати збалансовану систему показників, яка включає показники, що характеризують стратегію підприємства з чотирьох різних і тим не менш взаємозалежних перспектив: перспектива фінансів; навчання та зростання персоналу; внутрішні бізнес-процеси; перспектива клієнта. На основі індивідуально розроблених показників ефективності, наступного порівняння планових та фактичних даних керівники отримують інформацію, що дозволяє їм зробити оцінку ефективності реалізації стратегій в чотирьох основних вищевказаних сферах. Збалансована система показників інноваційної діяльностіє своєрідним засобом моніторингу та ефективним інструментом як поточного, так і довгострокового управління стратегією підприємства. Нами узагальнено та вдосконалено методику оцінки економічної ефективності організації інноваційної діяльності на промисловому підприємстві з використанням узагальнюючого показника ефективності роботи підприємства загалом. Запропонована система показників інноваційної діяльності допоможе підприємству проаналізувати його здатність до інноваційної роботи, якість здійснення цієї роботи, а такождозволить оцінити інноваційну активність підприємства, конкурентоспроможність продукції та фірми загалом.

Key words: innovation, efficiency, methodology, balanced scorecard, enterprise.

Ключові слова: інноваційна діяльність, ефектиВність, методика, збалансована система показників, підприємство.

\section{FORMULATION OF THE PROBLEM}

The decision to improve the innovative activity of the enterprise, including the decision to improve the model of its organization and development of the model of a comprehensive innovation process, requires an assessment of the economic efficiency of the activities being carried out.

In this regard, we consider it relevant to develop a methodology for determining the effectiveness of innovative activities of an industrial enterprise as a balanced scorecard.

\section{ACTUAL SCIENTIFIC RESEARCHES AND ISSUES ANALYSIS}

A lot of research has been devoted to the development of innovation. In particular, the scientific works of domestic and foreign scientists such as G. Goldstein, P. KapIan V. Koiuda, S. McCarthy, D. Mamotenko are devoted to the issue of assessing the innovative activity of enterprises. The works of these authors have investigated modern innovation management processes in industry and assessed the effectiveness of enterprise innovation activities. However, most aspects of determining the effectiveness of an enterprise's innovation activities remain under-researched, so it is especially relevant to investigate the assessment of the effectiveness of an industrial enterprise's innovation activities as a balanced scorecard.

\section{FORMULATING THE GOALS OF THE} ARTICLE (STATEMENT OF THE TASK)

The purpose of the article is to develop a methodology for determining the effectiveness of innovation activities of an industrial enterprise as a balanced scorecard.

\section{PRESENTATION OF THE MAIN RESEARCH MATERIAL}

The basic means of successful adaptation of the enterprise to the uncertain and rapidly changing conditions of the environment is an effective management mechanism that provides the formation and implementation of such a development option, which will provide the best possible final results in light of the current situation.

In general, efficiency is understood as the ratio of costs and results. The result of research and development (R\&D) works is the achievement of scientific, scientific and technical, economic and social effects. The scientific effect is characterized by the obtaining of new scientific knowledge and reflects the increase in information intended for "intrascientific" use. The scientific and technical effect characterizes the possibility of using the results of the research performed in other research and development $(R \& D)$ works and provides the information needed to create new products. The economic effect characterizes the commercial effect obtained by using the results of applied $R \& D$. The social effect is manifested in the improvement of working conditions, increase of 
economic characteristics, development of culture, health care, science and education [1].

Each enterprise has its own vision of the benefits of innovation, that is, the concept of efficiency itself has a relative nature. Therefore, we need a methodology for determining the effectiveness of innovative activities of an industrial enterprise, which will not only assess the existing innovations in the enterprise, but also form an optimal innovation portfolio.

The growing importance of innovative activities for the effective functioning and development of industrial enterprises involves significant investments, especially in technological innovations, because the timely change of technology ensures the competitiveness of the enterprise, and the correct technological policy is the basis for its prosperity. At the same time, investments in technological innovations are accompanied by greater risks than investments in already known and tested projects, especially since the probability of unsuccessful implementation of innovative projects increases significantly in conditions of increasing dynamism and uncertainty of the environment.

One of the ways to reduce the level of uncertainty (risk) in innovation is to diversify the output program of the enterprise, which will ensure the commercial and financial stability of the enterprise.

Thus, the representation of innovative activity in an industrial enterprise as a process of implementing a set of innovative projects gives us reason to use methods of portfolio planning of innovative activity, and also makes it necessary to conduct a comparative assessment of the effectiveness of innovative projects considered in the formation of an innovative portfolio of the enterprise. The purpose of the latter is not the choice of a single (best) project, but the choice of some set (portfolio) of innovative projects, which has a synergistic effect. Thus, the criterion of the effectiveness of innovative projects coincides with the criterion of the portfolio effectiveness.

Existing methods and practice of portfolio planning indicate that the composition and structure of the optimal portfolio is largely determined by the enterprise's strategy, on the type of which depends primarily the criterion of the effectiveness of the portfolio formation. Thus, for enterprises with a conservative approach, the highest priority is a strategy in which the resources of the enterprise, at a minimum, should be preserved. This type of enterprises does not tend to make risky decisions, so the criterion of maximizing income cannot be applied without taking into account risk, which is inherent in enterprises with aggressive type of strategy. The most often applicable strategy is the strategy of reasonable risk, in which the criterion of the task is an integral indicator that takes into account the income and risk of the portfolio at the same time.

We propose to assess the innovation activity with the help of certain indicators. However, we note that there cannot be a unified scorecard in market relations. Each investor independently determines this system based on the features of the innovation cycle, professionalism of specialists and managers, as well as other factors.

Currently, the innovation management system at most enterprises is one of the problem areas of activity.
Therefore, companies, as a rule, do not have enough experience to establish a scorecard of innovation activity.

Recently, more and more managers are trying to assess innovation with a system of numerical indicators. In doing so, enterprises use different approaches to measure their innovation activity, and only a few of them have at their disposal a coherent scorecard of innovation activity, which is in harmony with the strategic interests of the enterprise.

This tendency is due to the fact that the implementation of innovations that can be measured receive significantly more support from senior managers than innovations that are not calculable.

The current practice of innovation management is mainly limited to the following indicators: 1) the size of the annual budget for new developments (R\&D); 2) the percentage ratio of the R\&D budget to annual sales; 3 ) the number of patents received by the company during the reporting period; 4) the number of innovation proposals received from employees of the organization during the reporting period. These indicators can definitely be useful, but they do not measure the potential innovation capabilities of the enterprise and, therefore, will not be essential in the development of strategic decisions.

In addition to the above, at many enterprises innovations are considered as projects, and, therefore, the innovation management system in such companies is based on project management. In this case, the assessment of the effectiveness of innovations is carried out using "classical" financial indicators for project activities. These indicators are as follows: net present value (NPV), internal rate of return (IRR), rate of return, rate of return on net worth, financial autonomy ratio of the project, current liquidity ratio, and payback period of investment in an innovative project [2].

The coefficient of performance $(r)$ is used as an integral indicator characterizing the effectiveness of innovative activity of the enterprise:

$$
r=\frac{\sum R}{\sum_{i=1}^{N} Q_{i}-\sum_{i=1}^{N}\left(H_{2}-H_{1}\right)}
$$

where $R$ - is the total cost of completed works accepted (recommended) for mastering in serial production;

$Q_{i}-$ actual R\&D expenditures in the $i$-th year;

$N$ - number of years of the analysed period;

$\mathrm{H}_{1}$ - work in progress at the beginning of the analysed period in value terms;

$\mathrm{H}_{2}$ - the same at the end of the analysed period [3].

However, innovation is not a set of individual projects, but a continuous process of initiation, development and selection of innovative ideas, as a result of which new projects are born and implemented. Therefore, it is not always sufficient to apply "project" indicators to the measurement of innovation.

In our opinion, the system of innovation activity indicators should include not only financial indicators (ROI, share of profit from implementing innovations, etc.), but also qualitative indicators (share of ideas implemented in the company; average time elapsed from submission of a new innovative proposal to the decision to launch or abandon an innovative project, etc.). The dynamics of 
Table 1. Balanced scorecard of innovation activity of an industrial enterprise

\begin{tabular}{|c|c|c|}
\hline $\begin{array}{l}\text { Pos. } \\
\text { No. }\end{array}$ & Indicator & Characteristic \\
\hline \multicolumn{3}{|c|}{ Finance perspective } \\
\hline 1. & $\begin{array}{l}\text { ROI (return on innovation } \\
\text { investment) }\end{array}$ & $\begin{array}{l}\text { Can be calculated both for successfully } \\
\text { completed projects and for projects prepared for } \\
\text { implementation. It is calculated as the ratio of } \\
\text { the financial result of the innovation to the costs } \\
\text { of the innovation }\end{array}$ \\
\hline 2. & $\begin{array}{l}\text { The share of profit from } \\
\text { innovations in total profits over } \\
\text { the last } \mathrm{N} \text { years. }\end{array}$ & $\begin{array}{l}\text { It allows assessing the impact of innovations on } \\
\text { the enterprise's performance }\end{array}$ \\
\hline \multicolumn{3}{|c|}{ Training and personnel development } \\
\hline 3. & $\begin{array}{l}\text { The innovation index, i.e. the } \\
\text { relative share of innovative } \\
\text { products implemented over the } \\
\text { last } N \text { years in the total output of } \\
\text { the enterprise }\end{array}$ & $\begin{array}{l}\text { This composite indicator characterises the } \\
\text { innovation activity of the enterprise as a whole. } \\
\text { It makes sense to use it to compare the results } \\
\text { achieved by the enterprise with those of its } \\
\text { competitors, as well as with its own performance } \\
\text { in previous periods }\end{array}$ \\
\hline 4. & $\begin{array}{l}\text { Number of innovative ideas } \\
\text { generated by employees of the } \\
\text { enterprise within the last } \mathrm{N} \text { years }\end{array}$ & $\begin{array}{l}\text { By comparing the figures from the reporting } \\
\text { periods, it is possible to observe the dynamics of } \\
\text { the "innovation mood" in the enterprise, so that } \\
\text { in case of a decline in innovation activity, } \\
\text { measures can be taken in time to increase it }\end{array}$ \\
\hline \multicolumn{3}{|c|}{ Internal business processes } \\
\hline 5. & $\begin{array}{l}\text { The share of innovative ideas } \\
\text { implemented in the enterprise in } \\
\text { the total number of proposals put } \\
\text { forward }\end{array}$ & $\begin{array}{l}\text { This indicator allows measuring the efficiency } \\
\text { of innovative proposals }\end{array}$ \\
\hline 6. & $\begin{array}{l}\text { Average time elapsed from the } \\
\text { submission of a new innovation } \\
\text { proposal to the decision to launch } \\
\text { or abandon the innovation project }\end{array}$ & $\begin{array}{l}\text { Sub-optimal document flow procedures within } \\
\text { the enterprise, as well as inefficient decision- } \\
\text { making system, etc., may hinder the reduction of } \\
\text { this indicator }\end{array}$ \\
\hline \multicolumn{3}{|c|}{ Customer perspective } \\
\hline 7. & $\begin{array}{l}\text { The ratio of the number of } \\
\text { consumers using the enterprise's } \\
\text { innovations to the total number of } \\
\text { consumers }\end{array}$ & $\begin{array}{l}\text { This indicator allows assessing consumer } \\
\text { attitudes towards the enterprise's innovations }\end{array}$ \\
\hline 8. & $\begin{array}{l}\text { The ratio of the number of } \\
\text { complaints about the enterprise's } \\
\text { innovative products to the total } \\
\text { number of complaints }\end{array}$ & $\begin{array}{l}\text { This indicator allows assessing the quality of an } \\
\text { enterprise's innovation activities }\end{array}$ \\
\hline
\end{tabular}

changes in qualitative indicators will help identify problems in the innovation management system in time and take measures before a crisis occurs.

In addition, this system should become a part of the internal corporate scorecard and should be periodically reviewed taking into account changes in the company's environment.

In 1992, the Americans Kaplan and Norton proposed to assess the performance of the company using a balanced scorecard (Balanced Scorecard, BSC), which pays equal attention to both traditional financial and non-financial performance indicators of the company.

The introduction of BSC allows not only to identify the relationship between the decisions being made and the results of the enterprise, but also to transfer the strategy to the plane of operational management, focusing on those indicators that have the greatest impact on the value of the company [4].

"BSC: Criteria, Goals and Initiatives translate strategy into action... Goals and objectives cannot be achieved just by defining them-an organization must launch a whole set of programs through which all the intended indicators will be achieved. For each such program, the company must provide sufficient resources - people, funding, and capacity. We call these programs strategic initiatives. For each BSC indicator, managers must identify the strategic initiatives needed to achieve the goals. Initiatives generate results. Consequently, the implementation of the strategy is achieved through the implementation of initiatives" [5].

Due to the fact that today's market changes are much more rapid than before, financial indicators alone are no longer sufficient to assess performance. In addition, nonmonetary indicators are more closely linked to the longterm strategy of an enterprise.

It should be noted that while financial assessments reflect the performance of the enterprise for a certain period, non-financial ones allow comparing them with the expectations of customers and the achievements of competitors. Thus, if we supplement traditional indicators with non-financial ones, it will be easier for the company's senior managers to explain their goals to investors.

At the same time, such assets as the knowledge capital of the company, consumer loyalty, the potential of top managers, and brand promotion capabilities are becoming increasingly important in today's economy. These characteristics increase the value of the company and influence its competitiveness. However, because they are difficult to "translate into money", these indicators are of ten excluded from financial statements, thereby causing the company to make bad decisions. 
Thus, non-monetary indicators can serve as a better indicator of those financial results that have yet to be achieved. The use of a large number of different nonmonetary indicators in the statements allows correctly assessing the actions of the company's managers, and therefore contributes to the improvement of its performance [4].

Forming the BSC, the company must consider its strategy from four different and yet interrelated perspectives:

1. Finance perspective. No matter what different indicators are taken into account, the availability of accurate financial data will always be a basic management requirement. All of the goals and indicators included in the BSC must ultimately be subordinate to the achievement of specific financial goals. By linking financial indicators to non-financial indicators, the enterprise thereby demonstrates its intention to provide a financial return to investors.

2. Training and personnel development. An enterprise must assess its employees, its personnel management system, and the consistency of its organizational structure. This requires serious investment.

3. Internal business processes. Here it is important to find out in which processes the enterprise needs to achieve excellence, and to develop performance indicators for these processes.

4. Customer perspective. The enterprise needs to identify ways to increase its shareholder value. To do this, it is necessary to identify customer groups and business areas, as well as indicators to assess the main results, which will be significant for these groups and can be expressed in quantitative characteristics.

So, all of the above leads us to the fact that it is more appropriate to use a balanced scorecard to assess the innovative activity of the enterprise.

The balanced scorecard we propose can be applied to any enterprise engaged in innovative activities (Table 1).

After the above calculations have been made, an analysis of the efficiency of the enterprise's innovation activities should be carried out, the purpose of which is to examine its mechanism and to determine the return on investment.

Based on individually developed performance indicators and subsequent comparison of planned and actual data, senior managers receive information that allows them to assess the effectiveness of the implementation of strategies in four main areas. Thus, the balanced scorecard for innovation activity is a kind of monitoring tool and an effective tool for both current and long-term management of an enterprise's strategy.

Therefore, at the heart of innovation management is the determination of the effectiveness of innovative activity in order to improve it. In addition, when assessing the innovations carried out in the enterprise, it is necessary to remember about future innovation projects, the inclusion of which in the innovation portfolio also requires its assessment. We propose to carry out this assessment using the "classic" financial indicators for project activities discussed above.

In addition to all the above, let's pay attention to the fact that if in the process of enterprise management all the measures necessary for increasing the efficiency of its innovation activity are taken, the next cycle of innovation management will repeat at a higher level. As a result, this cycle will turn into the so-called "effectiveness spiral" with increase of effectiveness of innovation activity after each successful management cycle.

Furthermore, the main factors of the effectiveness of the enterprise as a whole, including the effectiveness of its innovative activity, are elements of the external and internal environment of the enterprise.

To assess the economic effectiveness of the organization of innovation activities in the industrial enterprise, in our view, it is advisable to use the generalizing indicator of the effectiveness of the enterprise as a whole, which can be calculated by the formula as follows:

$$
E=\frac{D-Q+\Delta Q}{C_{f a}+C_{c a}+C_{l r}}
$$

where $E$ is a generalizing indicator of the effectiveness of an industrial enterprise;

$D$ - revenue from the sale of innovations, both those produced in-house and those purchased externally;

$\mathrm{Q}$ - value of the total costs associated with the implementation of innovations in this enterprise;

$\Delta \mathrm{Q}$ - savings from reducing the total cost of production as a result of various kinds of measures, including measures to improve the innovation activities of an industrial enterprise;

$\mathrm{C}_{\mathrm{Va}}, \mathrm{C}_{\mathrm{ca}}$ - annual cost of maintenance and operation of basic production assets of the enterprise and current assets in inventories;

$\mathrm{C}_{\text {lr }}$ - cost of labor resources.

The results of the activities of an industrial enterprise in modern conditions are expressed in the form of total revenues from the sale of innovations produced in-house and from the sale of innovations purchased externally.

The ratio of the obtained result of production and economic activity with the costs of obtaining this result determines the effectiveness of the industrial enterprise.

The value of savings in total production costs $(\Delta Q)$ specified in the above formula for calculating the effectiveness indicator of an industrial enterprise is formed by the following components:

$$
\Delta Q=\Delta Q_{r}+\Delta Q_{m}
$$

where $\Delta Q_{r}$ is the direct savings of resources (mainly material) due to various factors;

$\Delta Q_{m}$ - savings resulting from improving the management of an industrial enterprise, including resulting from improving its innovation activities.

In their turn, savings resulting from improving the management of an industrial enterprise consist of the following elements:

$$
\Delta Q_{m}=\Delta Q_{m r}+\Delta Q_{i a}
$$

where $\Delta Q_{m r}$ - savings resulting from the improvement of enterprise management based on an increase in resource productivity;

$\Delta Q_{\text {ia }}$ - savings resulting from the improvement of innovative activities of an industrial enterprise.

The effectiveness of improving the innovation activities of an industrial enterprise can be determined by the 
formula as follows:

$$
E_{i a}=\frac{\Delta Q_{i a}}{Q_{i a}}
$$

where $\mathrm{E}_{\mathrm{ia}}$ - ratio of effectiveness of improving the innovative activity of an industrial enterprise;

$Q_{i a}$ - total cost of improving the innovation activities of an industrial enterprise.

The total cost of improving the innovative activity of the enterprise includes capital investment in improving the innovative activity of the industrial enterprise; the cost of research work for improving the innovative activity of the industrial enterprise; the cost of maintaining the administrative staff; other costs, including the cost of training and retraining carried out at the expense of the total cost of production.

Indicator $Q_{\text {ia }}$ provides an opportunity to assess the effectiveness of a set of measures to improve the innovation activities of an industrial enterprise operating in today's competitive environment.

The system of indicators of innovative activity will help the enterprise to analyse its ability to innovative work, quality of realization of this work, and also will allow assessing the innovative activity of the enterprise, competitiveness of products and firm as a whole, etc.

The balanced scorecard we propose allows us to assess an enterprise's innovation activities from four different and yet interrelated perspectives: finance (all about money), customer (how the enterprise manages customer needs), internal business processes (how the enterprise makes added value), training and development (how the enterprise manages knowledge). This system can be applied to any enterprise engaged in innovation activities.

\section{CONCLUSIONS}

Let us note that the system of innovation indicators creates the basis for managerial decisions, expressing the strategic interests of the enterprise and motivating the personnel to work proactively. However, even the most perfect system of indicators is only a tool, with the help of which the innovation management system is supported in the enterprise, and the susceptibility of personnel to innovations is the necessary condition, without which the innovation processes in the enterprise will not take place.

\section{Література:}

1. Гольдштейн Г.Я. Инновационный менеджмент: учебное пособие. Москва: ТРТУ, 2001. 324 с.

2. Мамотенко Д.Ю. Оцінка ефективності інвестиційних проектів. 2008. № 628, С. 209-216. URL: http:// vlp.com.ua/files/32_13.pdf (дата звернення: 21.04.2021).

3. Коюда В.О., Лисенко Л.А. Інноваційна діяльність підприємства та оцінка її ефрективності: монографія. Харків: ФОП Павленко О.Г., ВД "ІНЖЕК", 2010. 224 с.

4. Маккарти Шон. Четыре точки зрения на деятельность компании. Секрет фирмы. 2001. № 12.

5. Каплан Р., Нортон Д. Сбалансированная система показателей. От стратегии к действию $=$ The balanced scorecard. Москва: Олимп-Бизнесс, 2003. 282 с.
References:

1. Goldshtein, G.Ya. (2001), Innovatsionnyy menedzhment [Innovation Management], TRTU, Moscow, Russia.

2. Mamotenko, D.lu. (2008), "Assessment of the effectiveness of investment projects", vol. 628, pp. 209216, available at: http://vlp.com.ua/files/32_13.pdf (Accessed 21 Apr 2021).

3. Koiuda, V.O. and Lysenko, L.A. (2010), Innovatsiina diialnist pidpryiemstva ta otsinka yii efektyvnosti [Innovative activity of the enterprise and assessment of its effectiveness], FOP Pavlenko O. H., INZhEK Publishing House, Kharkiv, Ukraine.

4. McCarthy, S. (2001), "Four points of view on company performance", Sekret firmy, vol. 12.

5. Kaplan, R. and Norton, D. (2003), Sbalansirovannaja sistema pokazatelej. Ot strategii $k$ dejstviju = The balanced scorecard [The Balanced Scorecard: Translating Strategy into Action = The balanced scorecard], OlympBusiness, Moscow, Russia.

Стаття надійшла до редакчї 20.05.2021 p.

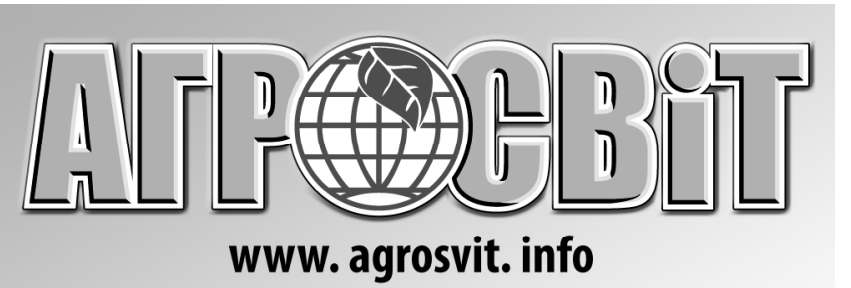

Передплатний індекс: 23847

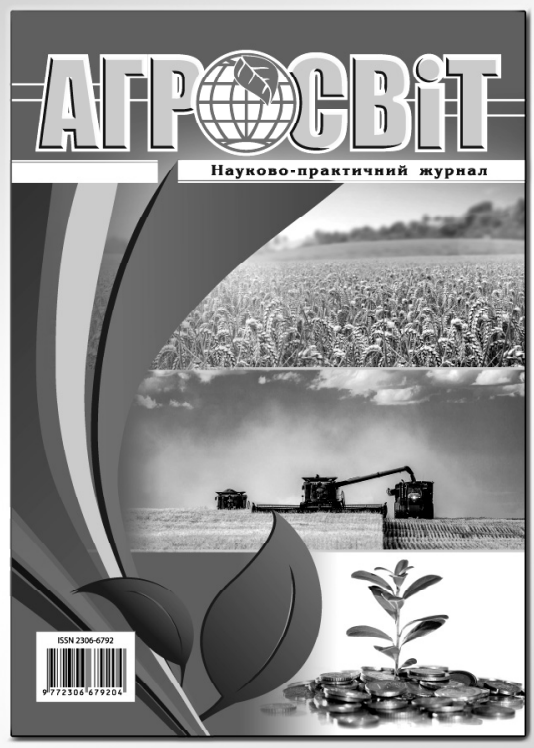

Виходить 24 рази на рік

\section{Хурнал включено до переліку наукових фахових видань України 3 ЕКОНОМІЧНИХ НАУК (Категорія «Б»)}

Спеціальності - 051, 071, 072, 073, 075, 076, 292 